\title{
Immune Reprogramming Precision Photodynamic Therapy of Peritoneal Metastasis \\ by Scalable Stem Cell Derived Extracellular Vesicles
}

Amandine Pinto ${ }^{1}$, Iris Marangon ${ }^{2}$, Julie Méreaux ${ }^{1}$, Alba Nicolás-Boluda ${ }^{2}$, Grégory Lavieu ${ }^{2}$ Claire Wilhelm ${ }^{2}$, Laure Sarda-Mantel ${ }^{3}$, Amanda K A Silva, ${ }^{2}$ Marc Pocard,${ }^{1+}$ Florence Gazeau $^{2+}$

${ }^{1}$ Université de Paris, Inserm UMR 1275 CAP Paris-Tech, F-75010 Paris, France; Service de chirurgie digestive et cancérologique Hôpital Lariboisière, AP-HP 2 rue Ambroise Paré, F75010 Paris, France.

${ }^{2}$ Université de Paris, Laboratoire MSC Matière et Systèmes Complexes, CNRS UMR 7057, 10 Rue Alice Domon et Léonie Duquet, 75205 Paris Cedex 13, France

3 Université de Paris, Service de Médecine Nucléaire, Hôpital Lariboisière AP-HP 2 rue Ambroise Paré, F-75010 Paris, France.

+ contributed equally, corresponding authors 


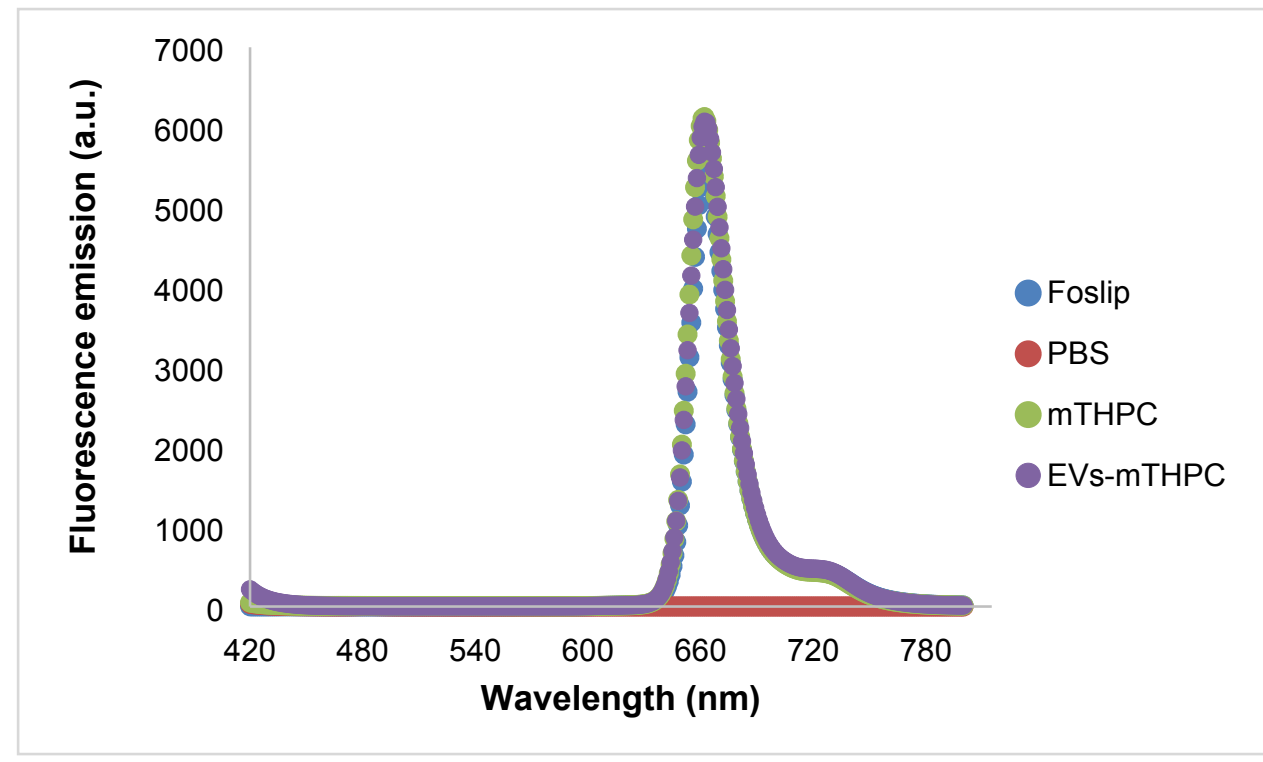

Figure S1: Fluorescence emission spectra of Foslip and EVs-mTHPC in comparison to mTHPC in PBS and PBS alone. Foslip and EVs-mTHPC show fluorescence emission equivalent to $\mathrm{mTHPC}$, attesting $\mathrm{mTHPC}$ encapsulation. 

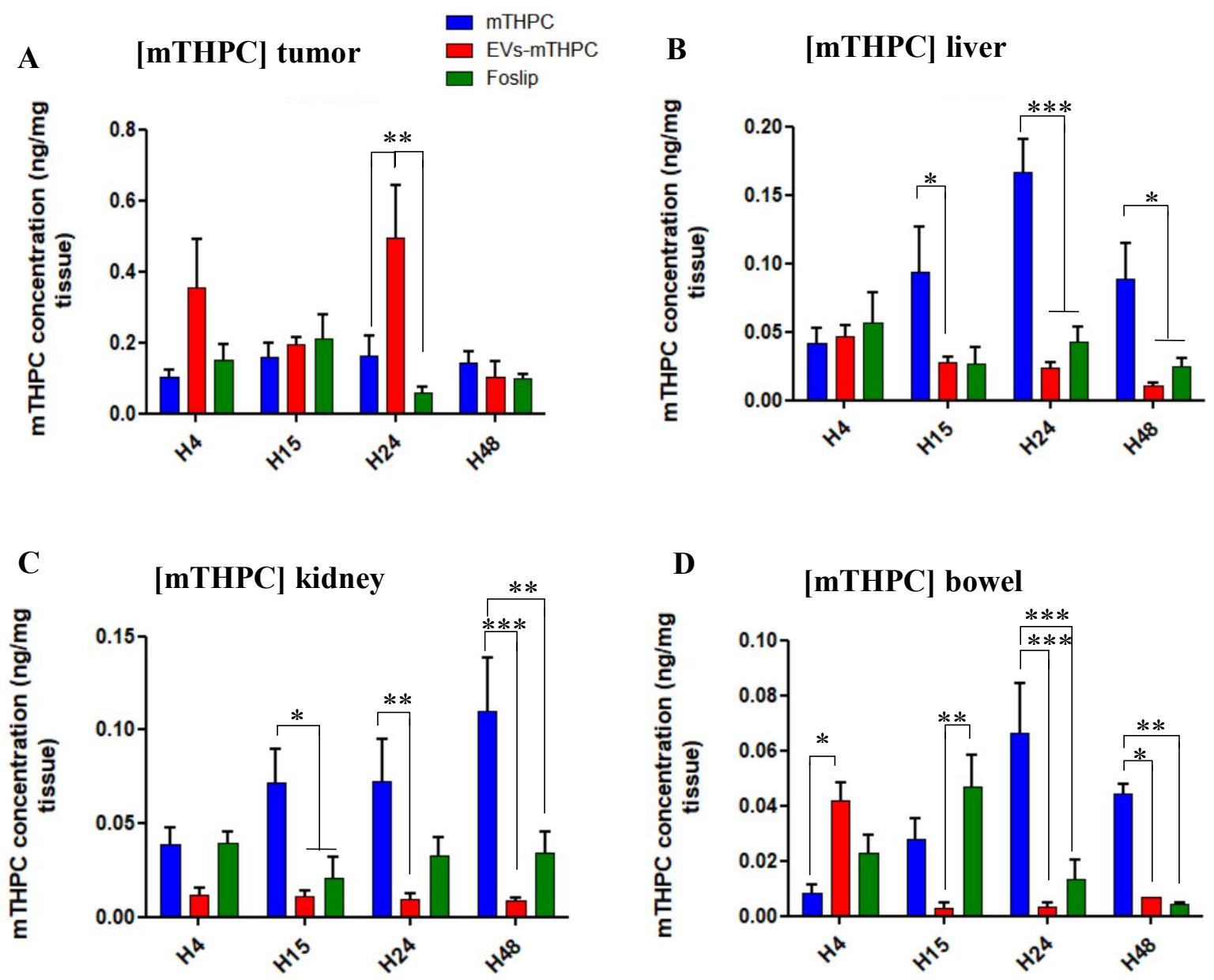

D

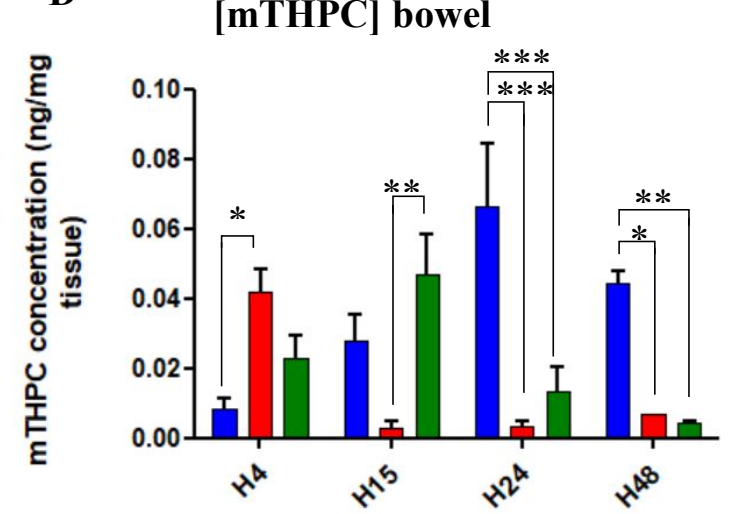

Figure S2: Pharmokinetics of $\mathbf{m T H P C}$ in the colorectal PM model. Direct comparison of mTHPC concentration in (A) tumor, (B) liver, (C) kidneys and (D) bowel at 4, 15, 24 and 48h post-administration depending on mTHPC formulation : free mTHPC, Foslip ${ }^{\circledR}$, EVs-mTHPC. $\mathrm{n}=4$ mice per time point and formulation; data are represented as mean \pm SEM (two-way ANOVA, $\left.{ }^{*} \mathrm{p}<0.05, * * * \mathrm{p}<0.0001\right)$. 


\begin{tabular}{|l|c|c|c|}
\hline $\begin{array}{l}\text { NIR } \\
\text { fluorescence } \\
\text { ratio }\end{array}$ & Tumor/Liver & Tumor/Kidney & Tumor/Spleen \\
\hline No treatment & 1.8 & 2.4 & 3.1 \\
\hline mTHPC & 1.3 & 3.4 & 7.4 \\
\hline Foslip & 2.0 & 6.2 & 8.7 \\
\hline EVs-mTHPC & 2.7 & 10.3 & 14.9 \\
\hline
\end{tabular}

B

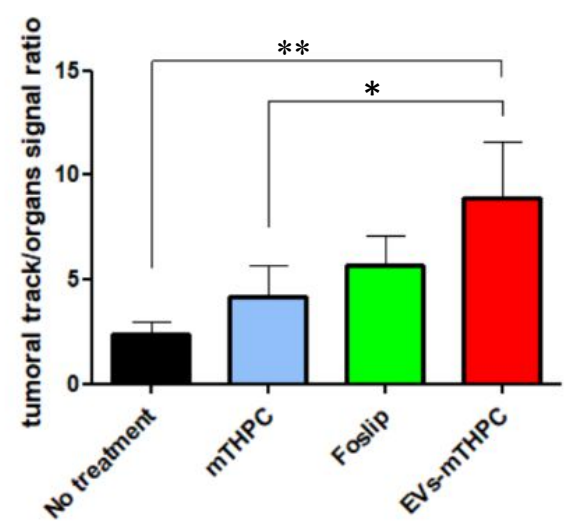

Figure S3: Liposomal and EVs-mTHPC membrane distribution in the colorectal PM model. (A) Ratio of NIR fluorescence intensity in the tumoral track over liver, spleen and kidney. (B) Ratio of NIR fluorescence intensity in tumoral track over the total other organs. ( $\mathrm{n}=6-8$ mice per formulation; data are represented as mean \pm SEM (one-way ANOVA, * $\mathrm{p}<0.05, * * \mathrm{p}=0.002)$. 


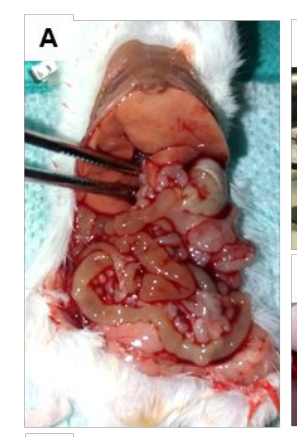

E
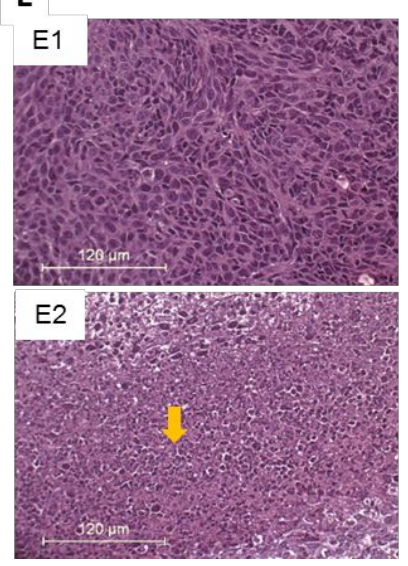

\begin{tabular}{|c|c|c|}
\cline { 2 - 3 } \multicolumn{1}{|c|}{$\mathrm{N}$} & \multicolumn{2}{c|}{ Number of dead mice } \\
\cline { 2 - 3 } \multicolumn{1}{c|}{} & Surgery + Laser illumination \\
\hline $\begin{array}{c}\text { EVs-mTHPC } \\
\text { concentration }\end{array}$ & Healty mice & $\begin{array}{c}\text { Tumor-bearing } \\
\text { mice }\end{array}$ \\
\hline $\mathbf{0 , 0 5} \mathbf{~ m g / k g}$ & $0 / 3$ & $0 / 3$ \\
\hline $\mathbf{0 , 1 5} \mathbf{~ m g / k g}$ & $0 / 3$ & $0 / 3$ \\
\hline $\mathbf{0 , 3 0} \mathbf{~ g / k g}$ & $3 / 4$ & $2 / 3$ \\
\hline
\end{tabular}

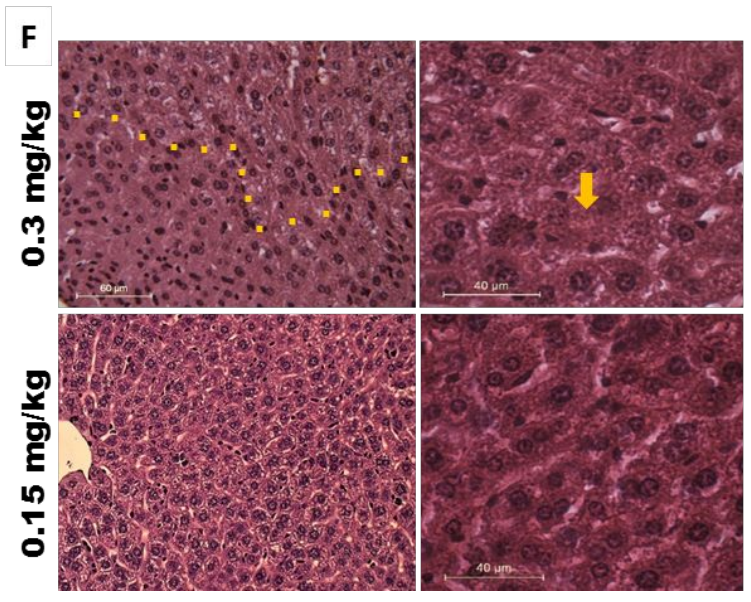

Figure S4: Toxicity of EVs-mTHPC-mediated PDT: set-up for laser irradiation and doseescalation in the colorectal PM model. (A) Picture of representative intraperitoneal disseminated nodules of CT26 tumors in mouse abdomen and (B-C) experimental set-up for PDT with laser beam focusing on the peritoneal cavity: mice underwent a laparotomy before illumination ( $\lambda=650 \mathrm{~nm}$ at $0,1 \mathrm{~W} / \mathrm{cm}^{2}$ for $\left.100 \mathrm{sec}\right)$. The peritoneum and the skin were separately sutured immediately after irradiation. The number of healthy and tumor-bearing mice dead post treatment is summarized in the table (D). The dose of $0,15 \mathrm{mg} / \mathrm{kg}$ was identified as suitable tolerated dose: mice responded positively to the treatment and histological analysis of nodules displays necrosis (E2) contrary to $0,05 \mathrm{mg} / \mathrm{kg}$ which induces no sign of necrosis (E1) (HE staining at 20x magnification). Liver injury with hepatocytes necrosis (F: area below dotted line) was observed after PDT at the dose of $0.30 \mathrm{mg} / \mathrm{kg}$ but not at $0.15 \mathrm{mg} / \mathrm{kg}$. 

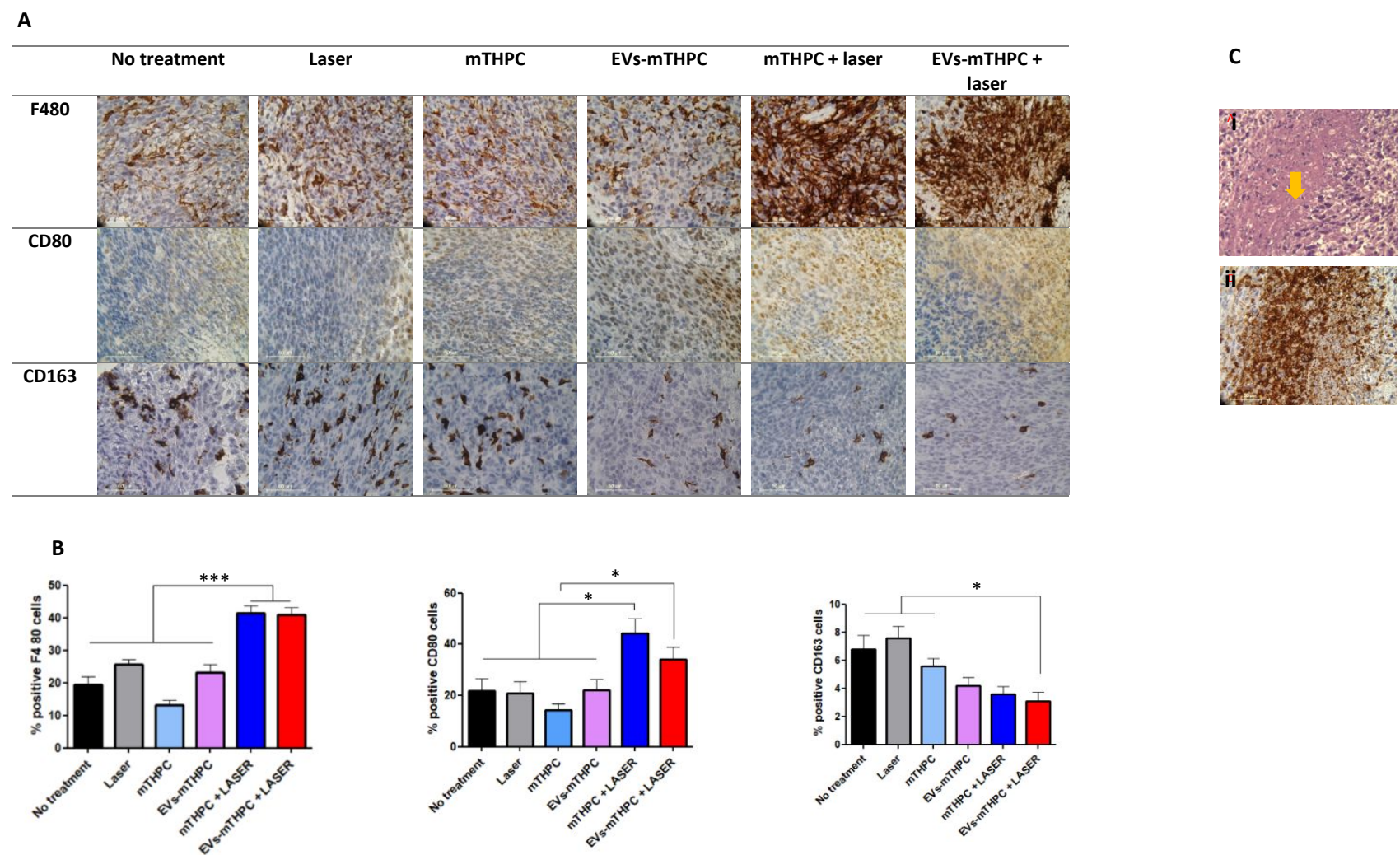

Figure S5: Outcome of PDT treatments on immune cell tumor infiltration in the colorectal

PM model. Representative images of IHC detection of macrophage invasion (F4/80), CD80+ M1-like macrophages and CD163+ M2-like macrophages in tumors of different groups (A). Quantification of immune cell infiltration in tumors: F4/80+ macrophages, M1-like CD80+ macrophages and M2-like CD163+ macrophages (B) (n=30/group, Kruskal Wallis test, ${ }^{*} \mathrm{p}=0.03,{ }^{*} \mathrm{p}=0.003, * * * \mathrm{p}<0.0001$ ). Spatial correlation between necrosis area (arrow) (i) and invasion of F4/80+ macrophages (ii) within a tumor from « EVs-mTHPC + laser » group (C). 

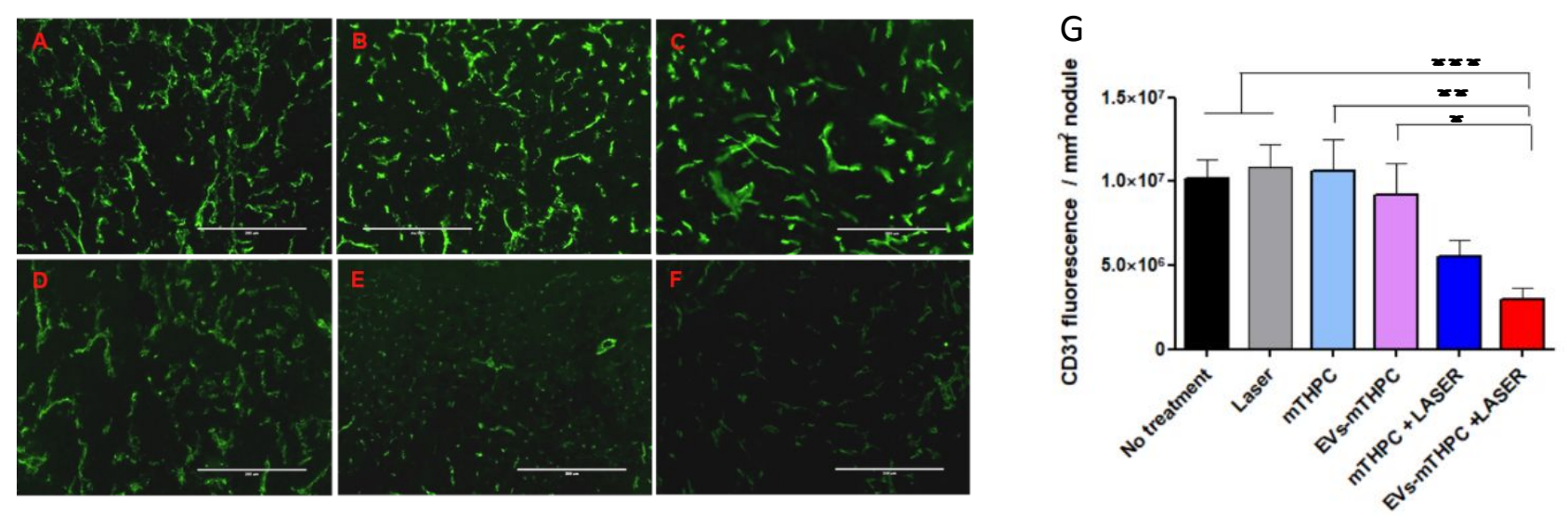

Figure S6: Outcome of PDT treatments on the vascular density in colorectal PM model. (A-F) Representative fluorescence microscopy of tissue cryosection stained with anti-CD31 antibody (scale bar $=200 \mu \mathrm{m})($ A: no treatment, B: laser, C: mTHPC, D: EVs-mTHPC, E: mTHPC + laser, F: EVs-mTHPC + laser) and (G) Quantification of CD31 fluorescence signal $\left(\mathrm{n}=15\right.$ per treatment, $\left.{ }^{*} \mathrm{p}=0.03,{ }^{*} \mathrm{p}=0.003, * * * \mathrm{p}<0.0001\right)$ 


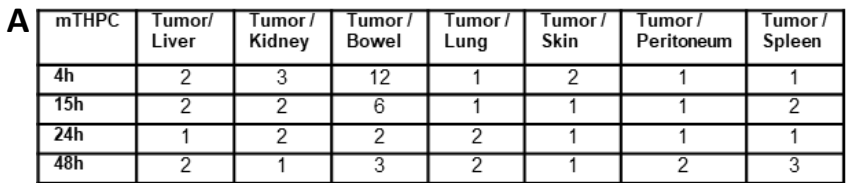

\begin{tabular}{|c|c|c|c|c|c|c|c|}
\hline $\begin{array}{c}\text { EVs- } \\
\text { mTHPC }\end{array}$ & $\begin{array}{l}\text { Tumor/ } \\
\text { Liver }\end{array}$ & $\begin{array}{l}\text { Tumor/ } \\
\text { Kidney }\end{array}$ & $\begin{array}{l}\text { Tumor/ } \\
\text { Bowel }\end{array}$ & $\begin{array}{l}\text { Tumor/ } \\
\text { Lung }\end{array}$ & $\begin{array}{l}\text { Tumor/ } \\
\text { Skin }\end{array}$ & $\begin{array}{l}\text { Tumor/ } \\
\text { Peritoneum }\end{array}$ & $\begin{array}{l}\text { Tumor/ } \\
\text { Spleen }\end{array}$ \\
\hline $4 \mathrm{~h}$ & 8 & 30 & $\overline{9}$ & 34 & 7 & 33 & 10 \\
\hline $15 \mathrm{~h}$ & 7 & 18 & 69 & 12 & 37 & 11 & 11 \\
\hline $24 \mathrm{~h}$ & 21 & 54 & 153 & 28 & 22 & 16 & 12 \\
\hline $48 \mathrm{~h}$ & 10 & 12 & 14 & 4 & 3 & 2 & 5 \\
\hline
\end{tabular}

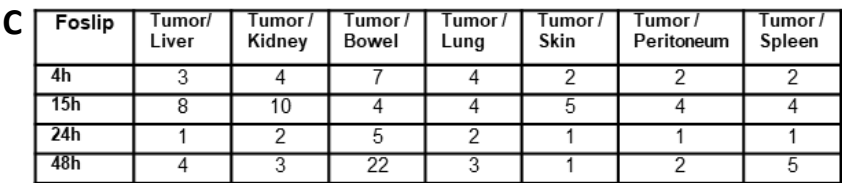

\begin{tabular}{|l|c|c|c|c|c|c|c|}
\hline $\begin{array}{c}\text { EVs- } \\
\text { mTHPC }\end{array}$ & $\begin{array}{l}\text { Tumor/ } \\
\text { Liver }\end{array}$ & $\begin{array}{l}\text { Tumor/ } \\
\text { Kidney }\end{array}$ & $\begin{array}{l}\text { Tumor/ } \\
\text { Bowel }\end{array}$ & $\begin{array}{l}\text { Tumor/ } \\
\text { Lung }\end{array}$ & $\begin{array}{l}\text { Tumor/ } \\
\text { Skin }\end{array}$ & $\begin{array}{l}\text { Tumor/ } \\
\text { Peritoneum }\end{array}$ & $\begin{array}{l}\text { Tumor/I } \\
\text { Spleen }\end{array}$ \\
\hline $4 \mathrm{~h}$ & 11 & 9 & 15 & 5 & 2 & 2 & 11 \\
\hline $15 \mathrm{~h}$ & 2 & 6 & 3 & 3 & 1 & 1 & 3 \\
\hline $24 \mathrm{~h}$ & 12 & 23 & 25 & 21 & 8 & 4 & 11 \\
\hline $48 \mathrm{~h}$ & 6 & 5 & 8 & 7 & 5 & 2 & 8 \\
\hline
\end{tabular}

\section{Table S1. Tissue distribution of mTHPC}

Tissue distribution of mTHPC at $4 \mathrm{~h}, 15 \mathrm{~h}, 24 \mathrm{~h}$ and $48 \mathrm{~h}$ after intraperitoneal injection of free mTHPC (A), EVS-mTHPC (B) and liposomal mTHPC (Foslip $\left.{ }^{\circledR}\right)(C)$ in the colorectal PM model and of EV-mTHPC in the ovarian PM model (D). Results are presented as mean concentration ratios of mTHPC in tumours and different normal tissues. 


\begin{tabular}{|c|c|c|c|c|c|c|c|c|}
\hline & $\begin{array}{l}\text { No } \\
\text { treatment }\end{array}$ & Laser & mTHPC & $\begin{array}{l}\text { EVs- } \\
\text { mTHPC }\end{array}$ & Foslip & $\begin{array}{l}\text { mTHPC } \\
+ \text { laser }\end{array}$ & $\begin{array}{l}\text { EVs- } \\
\text { mTHPC + } \\
\text { laser }\end{array}$ & $\begin{array}{l}\text { Foslip + } \\
\text { laser }\end{array}$ \\
\hline \multicolumn{9}{|l|}{$\begin{array}{l}\text { No } \\
\text { treatment }\end{array}$} \\
\hline Laser & 0.52 & & & & & & & \\
\hline mTHPC & 0.18 & 0.005 & & & & & & \\
\hline $\begin{array}{l}\text { EVs- } \\
\text { mTHPC }\end{array}$ & 0.21 & 0.08 & 0.97 & & & & & \\
\hline Foslip & 0.30 & 0.74 & 0.003 & 0.056 & & & & \\
\hline $\begin{array}{l}\text { mTHPC + } \\
\text { laser }\end{array}$ & 0.0001 & $<0.0001$ & 0.0003 & 0.001 & 0.0001 & & & \\
\hline $\begin{array}{l}\text { EVs- } \\
\text { mTHPC + } \\
\text { laser }\end{array}$ & 0.0002 & 0.0005 & $<0.0001$ & $<0.0001$ & 0.001 & $<0.0001$ & & \\
\hline $\begin{array}{l}\text { Foslip + } \\
\text { laser }\end{array}$ & 0.01 & 0.08 & $<0.0001$ & 0.001 & 0.18 & $<0.0001$ & 0.005 & \\
\hline
\end{tabular}

Table S2: P values of the log-rank test comparisons associated with Kaplan-Meier survival estimate shown in Figure 6. 